\title{
HIZMET, RELIGIOUS KNOWLEDGE, AND SCIENTIFIC EDUCATION*
}

\section{Mark Owen Webb}

Texas Tech University, Lubbock, Texas, USA. E-mail: webb@utt.edu

DOI: http//dx.doi.org/10.17666/31909-16/2016

\section{The Hizmet movement}

The Gülen movement, sometimes called the Hizmet movement, is an international movement of volunteers, organizing financial capital and human effort to serve the broader community. In the beginning, the movement was populated entirely by Turkish Muslims, and even today, most participants in the movement are motivated by religious faith. One of the values that the movement supports is the value of education, especially in the sciences. But knowledge claims in science and in religion frequently come into conflict with one another, or at least are perceived to come into conflict. This paper describes the particular problem for the Hizmet movement in terms of doxasticpractice epistemology, and outlines several ways potential conflicts can be dealt with. It closes with

* Conferência proferida em 28/10/2015 durante o 39º Encontro Anual da Anpocs, em Caxambu - MG. a suggestion for a particular method of resolution that respects the knowledge claims of both religion and science, but requires some sacrifice.

While it is impossible to put a precise date on the beginnings of movements like these, it is probably safe to say that the Gülen movement's educational efforts began in or around 1970, when the military influence on government underlined some of the strengths and weaknesses of Turkish secularism. Gülen started by establishing "lighthouses" which I will discuss later - and soon began encouraging his friends and associates to establish schools. ${ }^{1}$ As it became clear that the schools were producing students who were both good people and academic standouts, the movement widened its goals to encourage and improve the education available to all the children of Turkey. ${ }^{2}$

The most visible of the movement's educational institutions are the schools themselves. In Turkey, they are private schools from the elementary grades 
through high school. Although they are private, they are still subject to the same rules as the public schools, and offer exactly the same curriculum. They must also charge tuition, as do all private schools, but the sponsors of the schools also fund scholarships to ensure that this kind of education is available to the poor, as well. They are secular schools, even though those who established them have a religious motivation. They have two main aims: to prepare their students for further academic work by providing a good grounding in science, mathematics, and language; and to encourage good moral character, primarily by example. Religious subjects are not taught, except as objective academic subjects, as mandated by the secular government, but teachers are expected to model good moral character, and work extensively outside the classroom to encourage the students' academic and moral development. Since not all their students are Muslims, the schools are always careful to espouse only universal values that adherents of any religion, or even no religion, can respect. They meet with each of their students at least once every term, in their homes, to find out how they can help beyond their classroom duties. This means frequently spending every waking hour doing something related to teaching. Beyond the obligations associated with teaching, the teachers in these schools are often reassigned, as frequently as every two years. Since these teachers are not paid any more than public school teachers, taking such a position calls for an extraordinary commitment.

While these hizmet schools have been established in most major towns in Turkey, not every town and village has a school. For this reason, participants in the movement have also established dormitories in the cities and large towns, so that children from smaller towns and villages can attend the hizmet schools. The dormitories are staffed by teachers and others who help the students with their studies, provide a safe environment, and set a good moral example. Because of this commitment to a safe and wholesome environment, these schools and dormitories are attractive to parents who are otherwise not committed to the movement, too. ${ }^{3}$

Not all of those students who can attend hizmet schools are equally well-placed, financially or socially, to take advantage of their opportuni- ty. People in the Gülen movement establish study rooms for them. These study rooms provide extra study opportunities in the afternoons and on weekends. The aim is to make sure that every student in school has the chance to learn as well as possible, so that all have an equal chance to perform well on the standardized tests all Turkish schoolchildren take. The study rooms are open to students in the public schools, as well.

The Turkish high school (lise) system aims at preparing students for the country-wide college placement test. How a student performs on the exam determines what kind of college the student can attend, and so can make an enormous difference to the future course of the student's life. Because of this situation, institutions, called dershanes, have been established to help students prepare effectively for those exams, much like the institutions in America that are designed to help prepare students for the SAT, GRE, and the like. The people of the Hizmet movement have established dershanes of their own.

The first institutions to be established, in the early days of the the movement's educational efforts, are the "Lighthouses" (I $1 \mathrm{k}$ Evleri); these are houses provided for a small monthly contribution (or free of charge for those unable to pay) to University students who need a place to stay while they attend school. The students live an average of five to a house, one of whom is senior to the others and responsible for the house. They live a moderately austere life together and keep a modest Islamic household. In return for this accommodation, they are asked to be available to tutor high school children, and almost all express their gratitude by doing so. ${ }^{4}$

All these institutions are built and maintained by the financing of sponsors, businessmen who want to return some of their prosperity to the community. While many are quite wealthy owners of large businesses, there are sponsors of all degrees of prosperity. Some may underwrite the building of a new facility, others may fund scholarships, or support the educational efforts in more modest ways. The sponsors are a crucial part of the movement, but just as crucial are the people in the movement who contribute time and talent rather than money. Many of these grass-roots volunteers are previous beneficiaries of the institutions. Now that the 
movement is entering its second generation, even the sponsors are frequently people who have benefited from the schools and lighthouses. The guiding principles of the movement are hizmet (service) and korban (literally animal sacrifice, but in this context used metaphorically to denote any altruistic sacrifice), values that are rooted in Islam. They amount to the idea that it is an honor to serve the needs of others, and so people should be eager to serve, without expecting any reward. Further, to sacrifice for a good purpose is in religion a valuable act, so when your service requires you to give up something you value, your service is that much greater. As the movement has entered other parts of the world, especially Europe and the Americas, people from other religious traditions who share those values of service and sacrifice have joined in the movement's efforts.

\section{The nature of conflicting knowledge claims}

In being committed to broadly secular education, the movement is committed to the value of scientific knowledge in particular. Gülen himself [hiimself] speaks, as others have before him, of nature as a second source of revelation about the nature of God. In his view, and the view of others in the movement, the pursuit of scientific knowledge is critical to participation in the modern world, and also a religious duty. At the same time, the movement is rooted in a traditional, theologically conservative understanding of Islam, so what is revealed to humanity in the Qur'an and Hadith is accepted as known with certainty (though of course, individual's understandings of them are taken to be fallible). Christian and Jewish members of the movement have similar commitments to the authority of the Bible, and find the authority for their value-commitments there.

It is a commonplace in contemporary theory of knowledge that human beings avail themselves of many different ways to acquire knowledge. Our senses provide one avenue, memory another, reasoning yet another, and so on. Most of these avenues of knowledge are windows on the world; that is, they all provide information about the spatio-temporal world we all inhabit. As a result, they provide a generally consistent picture. When the deliverances of one sense contradict those of another, we see this as a problem that requires resolution, and usually, further application of the senses provides that resolution.

What is more controversial is the claim that there are ways of knowing that provide insights into aspects of reality other than the physical world. Moral sense and aesthetic judgment, if they are avenues of knowledge at all, are examples of this. There is no concern that either our moral sense or our aesthetic judgment will ever give us grounds for beliefs that contradict the deliverances of our senses. This is the normal situation, what is to be expected. Our sources of knowledge either agree with one another (in the long run), or give us information about completely different realms.

Suppose that, as some have said, religion provides a way of knowing. What are we to make of apparent contradictions between religious belief and science? This is a live issue in much of the world today, where fundamentalist interpretations of scriptures tell one story about the origin of life, and science tells another, and different people respond differently. If revelation, or scripture, or prophecy, tells us something that is contradicted by science, historically, religion has yielded to science, but that is not the only possible response to apparent conflict. In what follows, I hope to lay out the different logically possible positions people can take on the relation between science and religion, and show how this analysis makes trouble for the idea of religion as an avenue of knowledge.

To begin with, we can divide the possible positions into two kinds: you can think either that science and religion are incompatible, that is, that the claims the two systems make cannot all be true, or that they are compatible. If you think they are incompatible - call this view Pessimism - you have a decision to make. If they can't both be right, you know one of them is wrong, but the incompatibility alone doesn't tell you which one. So, some people, having great faith in the ability of science to get at the truth about the world, have decided that religion is intellectually disreputable, and so abandon all religious claims. Daniel Dennett, ${ }^{5}$ Richard Dawkins, ${ }^{6}$ and virtually every enlightenment athe- 
ist that ever was take this view. They believe science is by its nature directed toward truth, and there is no reason to suppose that religious traditions have that same truth-directed quality. If this view is right, then religion, to remain viable, must revise its doctrinal commitments.

But not all pessimists are scientific pessimists. Some, reasoning that science admits it is fallible, but that God (or the Vedas, or the Buddha) cannot be wrong, decide to jettison science instead. In this camp we find creationists, and Intelligent Design theorists like William Dembski. ${ }^{7}$ It's important to understand that it is not only Christianity that harbors religious pessimists of this kind. In the late eleventh and early twelfth centuries, a Muslim philosopher named Al-Ghazzali applied rigorous logical reasoning to matters of cosmology and philosophy, and decided that the whole enterprise was self-refuting. He then gave up philosophy, became a Sufi mystic, and wrote a book called The Incoherence of the Philosophers. ${ }^{8}$ He would say that if reason contradicts God, then so much the worse for reason. $\mathrm{He}$ would surely make the same judgment about science, which is, after all, just a regimented form of common sense, a way of reasoning about the world. Moreover there are Hindus and Buddhists who take their scriptures' claims about the origin of the universe and humankind as literally true, and therefore reject the claims of modern science. It used to be part of Hindu and Buddhist orthodoxy that there is a huge mountain, Mount Meru, at the center of the earth, which is flat and disk-shaped, and the continents are banana-shaped land masses arranged around the central hub. ${ }^{9}$ To this day, many Hindu fundamentalists take issue with the theory of evolution, not because it makes the earth too old, but rather too young. They claim that human beings have inhabited the earth for millions of years. ${ }^{10}$

Actually, there is a third kind of pessimist position one can take, but it isn't very popular: You can think, like Tertullian, the second and third century Christian thinker, that science and religion are incompatible, and that is perfectly OK. It's a little funny to talk about second century "science," since science is really a modern idea, but there certainly was an idea of knowledge of the natural world then. Tertullian is famous for having said "Credo quia ab- surdum est," 11 which means "I believe it because it doesn't make any sense." He thought that the very inconsistency of Christian doctrine with common sense was a mark in its favor. For him, incoherence is not a problem. That's an odd position, not shared by many, but it is - in some sense - a possible view.

But one can also be an optimist, and think that science and religion do not ultimately contradict one another. Optimists come in two kinds, that I will call Cowardly and Bold. The cowardly optimist believes that science and religion are compatible because they are not talking about the same thing. Just as quantum physics and literary theory are compatible, because they are not even addressing the same subject, religion talks about one thing, and science another, so there is no occasion for incompatibility. Setphen J. Gould, in his Rocks of Ages $^{12}$, argues for a position like this. He calls this idea Non-Overlapping Magisteria (borrowing the idea of magisterium, or teaching authority, from Catholic doctrine). Of course, as I have pointed out earlier, religions do make claims about some of the same things science talks about, including cosmology, geography, history, psychology, and more. So Gould has to modify his claim; he has to say that science and religion ought not to talk about the same things. It's a noble idea, I suppose, but it's not likely to make converts of either scientific or religious pessimists. That's why it's cowardly: it buys compatibility at the price of forbidding discussion.

Finally, one can be a bold optimist. This is the view that science and religion are compatible because they are both avenues of knowledge about the one reality we all inhabit. Truth has nothing to fear from truth, so scientific truth and religious truth will converge on the same picture of the universe. It does require courage, though, because there will be cases in which the claims of science and the claims of religion seem to conflict, and then the bold optimist has a decision to make. In some ways, it is an inherently unstable position. The fact that religious belief and science seem to come into conflict over and over again suggests that they are not both avenues of knowledge about the same spatio-temporal world. One of the reasons to think that our senses are an adequate guide to the nature of the world is that they tend, in the long 
run, to confirm one another. The appearance of fire is accompanied by the sensation of heat, and so on. As we noted in the beginning, when there is conflict, further investigation with the senses tends to resolve it. Historically, what has happened with science and religion is somewhat different; when they come into conflict, there is no mutually agreed-on method of inquiry that can be used to resolve the conflict. What has always happened (so far) is that when science has asserted something inconsistent with religious doctrine, eventually the doctrine has changed. It does not happen that some method of religious inquiry is undertaken that resolves the problem; instead, there is a process of reinterpretation. Whereas the early Catholic Church [church] believed that geocentrism was essential to Christian doctrine, now the church has found a way to interpret its scriptures less literally. It is to be hoped that the idea of a literal six-day creation is similarly on its way out (as most branches of Christianity have already decided). Which strategies are open to the Hizmet movement? It seems that, since they are committed to both science and revealed religion, they must opt for an optimistic stance.

\section{A doxastic practice analysis}

As noted above, human beings acquire knowledge in lots of different ways. If we consider each of these avenues of knowledge in isolation as much as possible, we can discern a certain structure to them. Take sense-experience as a model of a generally trustworthy avenue of knowledge; it has several interesting general features. First, it consists of a cluster of interrelated mechanisms that have an experience as an input, and a belief as an output. Of course, it has outputs of kinds that are not aptly described as belief-like, but it prominently features beliefs about the external world as outputs. Second, it is a natural and unavoidable part of a human being's cognitive system that is firmly established in human life. Third, it is deeply embedded in our more general practices of moving around the world and accomplishing things. Finally, it is understood as being fallible, as particular sense-experiential claims can be overridden by information gathered from other people, or from other avenues of knowledge, like deductive reasoning. Following William Alston, I will call sources of belief like these Doxastic Practices.

Different doxastic practices involve distinctive input-output relations, and involve their own distinctive defeater systems. So memory produces beliefs about the past, deductive reasoning produces beliefs about entailment relations among propositions, inductive reasoning produces beliefs about what one is likely to discover in the future (even when the discovery is about the past), and so on. According to the doxastic-practice approach, rather than ask if a particular belief is justified, the question is whether the individual practice is reliable, and so rational to engage in.

It should be obvious that there is something unsatisfactory about using the outputs of a practice to show that the practice is reliable. For example, it is not satisfactory to claim that we know sense-perception is largely reliable because it has so often turned out to be right. This is because the way we know it has turned out to be right is by further applications of sense-perception. While this self-checked record of success does show a deep and rich coherence in the practice, it doesn't show reliability any more than a gang of thieves show they are not lying because each one confirms the others' stories. Also, we can't generally use one practice to show the reliability of another, because they generally don't operate in the same realms.

There can be, however, clear indicators of unreliability. If a practice produces pervasive, persistent, ineliminable contradictions, then it cannot be generally reliable. After all, reliability is a matter of producing a large proportion of true outputs, and contradictions cannot be true. One reason we can dismiss practices like astrology and crystal-ball gazing is that they frequently produce contradictory outputs. Also, even when they don't contradict themselves, they frequently produce outputs that contradict the outputs of other practices, like sense-perception. If a voluntary practice like astrology contradicts an indispensable [indispensable] one like sense-experience, then it is clear that astrology has to go. In general, if one practice consistently produces outputs that contradict the outputs of more central, more firmly-established practices, 
we take that to mean the less established practice is unreliable. So while it is impossible to show a practice is reliable without resorting to circular reasoning, we can show that a practice has not been proved unreliable, if it has avoided massive, persistent and ineliminable contradiction, either with itself or with better-established practices.

In his book Perceiving God ${ }^{13}$, William Alston argues that at least the Christian practice of forming religious beliefs on the basis of mystical experiences is rationally engaged in, and is therefore reasonable to suppose to be reliable. Alston argues that the Christian Mystical Practice exhibits all the same features as our standard package of doxastic practices. It is socially established, and does not produce important, ineliminable, massive inconsistencies, either internally or with respect to our other practices. It is also the only game in town for coming into perceptual contact with the divine. It is impossible to produce a direct argument for the reliability of the practice without appealing to its own outputs, but the same is true of sense perception, so that is no disability. ${ }^{14}$

Critics of the doxastic practice approach point out that the argument they make for the rationality of religious belief based on religious experience is potentially available to the adherents of all religions ${ }^{15}$, and so provides no special support for the Christian beliefs they favor. This presents a serious challenge, because if it is true that more than one religious practice can deem itself rational on these grounds, and the two practices produce results that systematically contradict one another, then that is sufficient to show that one of them is in fact unreliable. In that case, there is also no independent way to establish which one is unreliable. Alston admits that it is possible that adherents of other religions might well be able to make a similar case for their own practices, but he also points out that a) they may, in fact, not be able to make the case, since it depends upon facts about the history of the practice which may not obtain in a particular case, and b) even if it did, that fact does nothing to undermine the case for Christian mystical practice; the argument that supports its rationality still does so.

\section{A happy resolution?}

For what follows, I will assume that the adherents of the world's major religions can mount the same argument for the rationality of religious belief as Alston does for Christian belief. In that case, it certainly seems that members of the movement have excellent reason to trust the outputs of science, since they have the same reasons to accept science that all others do; and they have excellent reason to accept the tenets of their own religion, and their own confirming experiences of it. Their acceptance of science is deeply embedded in their understanding of their educational goals. To understand the universe is in itself a good thing, and educating children in science will make them better citizens. Their acceptance of revealed religion is frequently a large part of their motivation to engage in the activities of the movement. So, to remain who they are, they must adopt an optimistic stance: that apparent conflicts between science and religion are merely apparent, and can be resolved. Also, they cannot really adopt a cowardly optimism, because it is part of their understanding of revelation that their revelations include factual information about the world. So they must be bold.

Undoubtedly, there are religious people who are uncomfortable with different assertions of contemporary science. There are, for example, Christian and Muslim anti-evolutionists, and some are volunteers in the Hizmet movement. Gülen decries materialism in general, but he does not specifically oppose evolutionary biology. So as long as metaphysical materialism is not a commitment of science, and many scientists certainly don't think it is, there need be no general conflict. But still, the danger is always there. Whether it is Psychology, or Evolutionary Biology, or Big Bang Cosmology, the danger is always present that scientists will make some pronouncement that is unsettling to some religion's doctrine.

There are really only two strategies available to the bold optimist: either change his/her [your] understanding of what his/her [your] religion requires, or hold on to hope that future science will show that earlier science was wrong, and something compatible with religion is in fact true. And as the optimist says, truth has nothing to fear from truth, so we should expect them to agree in the end. 
The first strategy amounts to admitting we were wrong in our previous understanding. To do that, we need to be able to produce a good reason for the new understanding, so that it is not merely twisting the sacred text to suit our needs. That would be a shameful dishonesty. There are, fortunately, honest ways of letting go of earlier understandings. One principle Gülen himself has used to explain passages that others find difficult, or even contradictory, is to distinguish verses addressed to particular situations from verses that express universal principles. The Qur'an's general prohibition on killing people is not qualified; the particular occasions on which permission is given, or a command is given, to kill someone, there are always carefully delimited circumstances. The general principle is deeper, so any reading of the Qur'an that makes killing unbelievers, for example, a general duty for Muslims is a misreading. Likewise, when a reading of a text seems to require something problematic from the point of view of general fairness, like counting a woman's testimony as worth half of a man's, an exploration of the reason behind the text reveals that it was rooted in circumstances of the time that no longer hold. Again, the general principle trumps the less general rule. This is frequently what is going on when an interpreter tries to separate out what is cultural from what is religious. If a practice can be traced to the Hellenistic culture of the first century, or the Arabian culture of the seventh and eighth centuries, then the particular practice can be seen as cultural, and therefore not binding on all believers.

Of course, it is possible for an apparent contradiction to arise that cannot be alleviated by such a hermeneutical strategy. Christian creationists, for example, think the literal reading of Genesis is non-negotiable. There is no way to see it as a qualification of or exception to a particular rule, nor can it be (they say) understood as a feature of the culture of the middle east that serves a purpose that can be served by other means. Their only choice, and the only choice for those in the same situation, is to maintain that current science is wrong. This is not as crazy as it might sound, because as we know, science continues to progress by means of finding out new things, about which we were wrong be- fore. At one time, the luminiferous ether was a part of current physics, and phlogiston was part of current chemistry. Perhaps we can be confident that our understanding of religious doctrine is sound, but that if we hold out for future science, we will be vindicated. Scientific revolutions happen; the current understanding is frequently replaced by something completely new.

The trouble with this strategy is that in many cases, it is simply extremely implausible. True, scientific revolutions happen, and correct mistakes in accepted science. But they never completely overturn the current understanding. The mass of evidence that supported the previous view is not overturned, just organized in a new way. To extend the example of Biblical creationism, it is reasonable to hope that evolutionary theory will refine and ramify, but is not reasonable to hope that we will return to a pre-Darwinian understanding. The facts about fossil dating and genetic transmission of characteristics must be a part of any future biology, and so there is no room for either a 6000-year-old earth, or for completely unrelated, independentlycreated species. We may give up on the big bang, but we will never go back to the crystal spheres with the earth at the center of the universe. So if a religious doctrine seems to require a pre-modern understanding of some part of the universe, it is not a reasonable strategy to wait for new scientific discoveries to vindicate the pre-modern view.

\section{The prospects for the Hizmet movement}

Since the Hizmet movement is committed to both the value of science and the value of religious revelation, there seems to be no option but to be bold optimists. So far, it seems to have worked for them. The only question for them to consider is about possible future conflicts. Pessimism of both kinds is untenable for them, as is cowardly optimism. Likewise, the prospects are bleak for science to give up current theories to revert to earlier ones. So they should admit fallibility, be prepared to abandon cherished interpretations, and explore new ways of understanding scripture. Boldness sometimes requires sacrifice. 


\section{Notas}

1 Yüksel A. Aslando an, and Muhammed Çetin, "The Educational Philosophy of Gülen in Thought and Practice," In Muslim Citizens of the Globalized World: Contributions of the Gülen Movement, ed. Robert A. Hunt and Yüksel A. Aslando an, (Somerset, NJ: Light Publishing, 2006), 31-54.

2 For a nice discussion of Gülen's ideas about the relation between Islam and education, see Bekim Agai, "The Gülen Movement's Islamic Ethic of Education," In Turkish Islam and the Secular State: the Gülen Movement, ed. Hakan Yavuz and Joseph Esposito (Syracuse, NY: Syracuse University Press, 2003), 48-68.

3 Berna Turam, Between Islam and the State: the Politics of Engagement (Stanford, CA: Stanford University Press, 2007), 63.

4 M. Hakan Yavuz, "The Gülen Movement: the Turkish Puritans," In Turkish Islam and the Secular State, ed. Hakan Yavuz and Joseph Esposito (Syracuse, NY: Syracuse University Press, 2003), 32-34.

5 Breaking the Spell, New York: Penguin, 2006.

6 The God Delusion, New York: Bantam Books, 2006.

7 The Design Revolution: Answering the Toughest Questions about Intelligent Design, Downer's Grove, IL: Intervarsity Press, 2004.

8 Michael E. Marmura, trans., Salt Lake City: Brigham Young University Press, 2002.

9 Akira Sadakata and Hajime Nakamura, Buddhist Cosmology, Tokyo: Kosei Publishing Company, 1997.

10 See sources cited in Michael Cremo and Richard L. Thompson, Forbidden Archeology, Bakhtivedanta Books Publishing, 1998.

11 Tertullian, On the Flesh of Christ, Kessinger Publishing, 2010.

12 New York: Ballantine Books, 1999.

13 William P. Alston, Perceiving God: The Epistemology of Religious Experience (Ithaca, N.Y.: Cornell University Press, 1991).

14 This paragraph is a summary of the argument of Perceiving God.

15 Whether the arguments are actually available to the other religions depends on whether those other religious practices are sufficiently coherent, among other things. 


\section{HIZMET, CONHECIMENTO RELIGIOSO E EDUCAÇÃO CIENTÍFICA}

\section{Mark Owen Webb}

Palavras-chave: Movimento Hizmet; Religião e Ciência;

O movimento Gülen Hizmet é um movimento internacional de voluntários, que organiza capital financeiro e esforço humano a serviço da comunidade mais ampla. No início, esse movimento foi constituído inteiramente por muçulmanos turcos e, ainda hoje, a maioria dos que nele participam são motivados pela fé religiosa. Um dos valores sustentados pelo movimento é o valor da educação, especialmente nas ciências. Mas as exigências do conhecimento na ciência e na religião são frequentemente conflitivas entre si. Este artigo descreve o problema que se coloca em particular para o movimento Hizmet em termos da epistemologia da prática doxística, e delineia várias maneiras pelas quais se pode lidar com seus potenciais conflitos. Ele conclui com uma sugestão de um método particular de resolução que respeita as exigências de conhecimento tanto da religião como da ciência, conquanto requeira algum sacrifício.

\section{HIZMET, RELIGIOUS KNOWLEDGE, AND SCIENTIFIC EDUCATION}

Mark Owen Webb

Keywords: Hizmet Movement; Religion and Science; Volunteers

The Gülen Hizmet movement is an international movement of volunteers organizing financial capital and human effort to serve the broader community. In the beginning, the movement was entirely populated by Turkish Muslims and, even today, most of its participants are motivated by religious faith. One of the values supported by the movement is that of education, especially in the sciences. But knowledge claims in science and in religion frequently come into conflict with one another. This paper describes the particular problem for the Hizmet movement in terms of doxastic-practice epistemology, outlining several ways in which potential conflicts can be dealt with. It closes with a suggestion for a particular method of resolution that respects the knowledge claims of both religion and science, but that requires some sacrifice.

\section{HIZMET, SAVOIR RELIGIEUX ET ÉDUCATION SCIENTIFIQUE}

Mark Owen Webb

Mots-clés: Mouvement Hizmet; Religion et Science; Bénévolat.

Le mouvement Gülen Hizmet est un mouvement international de bénévoles qui organise du capital financier et de l'effort humain au service de la communauté au sens large. Ce mouvement a été, à l'origine, constitué uniquement par des musulmans turcs et, actuellement, la majorité des participants sont motivés par la foi religieuse. Une des valeurs défendues par le mouvement est celle de l'éducation, particulièrement dans le domaine de la science. Mais les exigences du savoir en matière de science et de religion sont fréquemment conflictuelles. Cet article décrit le problème qui se pose, en particulier pour le mouvement Hizmet, en termes de l'épistémologie de la pratique de la doxologie, et propose des alternatives par lesquelles il serait possible de faire face à ces conflits potentiels. Il suggère, en conclusion, une méthode particulière de résolution qui respecte les exigences de savoir aussi bien de la religion que de la science, même si cela requiert un certain sacrifice. 